\title{
Paleoproterozoic serpentinites of Eseka, Cameroon: Evidence of a suture zone between the Congo and São-Francisco cratons.
}

\author{
Estelle Philomene Nga Essomba ${ }^{1}$; Brice Kamguia Woguia ${ }^{1}$; Gus Djibril Kouankap Nono ${ }^{2}$ \\ Sylvestre Ganno ${ }^{1}$; Jean Paul Nzenti ${ }^{1}$ \\ ${ }^{1}$ Department of Earth Sciences, University of Yaoundé I, P.O. Box. 3412, Messa, Yaoundé, Cameroon \\ ${ }^{2}$ Department of Geology, HTTC, University of Bamenda, P.O. Box 39, Bambili, Bamenda, Cameroon \\ *Corresponding author: nphiloesso2@gmail.com (E.P. Nga Esssomba)
}

The geodynamic evolution of the Eseka is investigated by means of geochemistry and petrology of serpentinites closely associated with Paleoproterozoic eclogitic metabasites. These rocks are characterized by pseudomorphic textures, including mesh microstructure, formed by serpentine intergrowths, with cores of olivine, bastites after pyroxene. Two distinct types of serpentinites are highlighted. Type 1 with high $\mathrm{MgO}(40 \mathrm{wt} \%)$ content and high $\mathrm{Mg \#}$ values (88.80); whereas Type 2 serpentinites display relatively low $\mathrm{MgO}$ concentration and $\mathrm{Mg \#}$ values (40 and $82.88 \mathrm{wt} \%$, respectively). Both types have low $\mathrm{Al} / \mathrm{Si}$ and high $\mathrm{Mg} / \mathrm{Si}$ ratios than the primitive mantle, reflecting a refractory abyssal mantle peridotite protolith. Partial melting modeling indicates that these rocks were derived from melting of spinel peridotite before serpentinization. Bulk rock high-Ti content is similar to the values of subducted serpentinites $(50 \mathrm{ppm})$. This similarity, the high $\mathrm{Cr}$ contents, spinel-peridotite protolith compositions and $\mathrm{Mg} / \mathrm{Si}$ and $\mathrm{Al} / \mathrm{Si}$ ratios imply that the studied serpentinites were formed in a subduction related environment. The U-shaped chondrite normalized REE patterns of serpentinized peridotites, coupled with similar enrichments in LREE and HFSE, suggest their refertilized nature due to melt/rock interaction prior to serpentinization. Based on the results, we suggest that the Eseka serpentinized peridotites are mantle residues that suffered a high degree of partial melting in a subduction related environment, especially in Supra Subduction Zone setting. These new findings suggest that the Nyong series in Cameroon represents an uncontested Paleoproterozoic suture zone between the Congo craton and the Sao Francisco craton in Brazil. 